REVIEW

\title{
Anti-tumour necrosis factor $\alpha$ therapy in rheumatoid arthritis: an update on safety
}

\author{
K L Hyrich, A J Silman, K D Watson, D P M Symmons
}

Ann Rheum Dis 2004;63:1538-1543. doi: 10.1136/ard.2004.024737

Anti-TNF $\alpha$ therapy may have associated risks of serious infection, congestive heart failure, malignancy, and multiple sclerosis. The magnitude of these risks is difficult to assess. This article reviews publications on the current knowledge about the safety of these agents.

See end of article for authors' affiliations

Correspondence to: Professor A J Silman, ARC Epidemiology Unit, Stopford Building, University of Manchester, Oxford Road, Manchester M13 9PT, UK;

alan.Silman@man.ac.uk

Accepted 20 June 2004 Published Online First 8 July 2004
A gents that block the action of tumour necrosis factor $\alpha(\mathrm{TNF} \alpha)$ are established as effective agents in the treatment of rheumatoid arthritis (RA), especially in patients with disease unresponsive to standard disease modifying antirheumatic drugs (DMARDs). ${ }^{1}$ Blockade of this cytokine is likely to have effects beyond the suppression of synovial inflammation and there is concern that such effects might be associated with severe adverse events.

Data on the frequency of adverse events come predominantly from three sources: follow up of subjects recruited to clinical trials, surveillance of patients treated in routine practice, and spontaneous reporting to national pharmacovigilance systems. The drawbacks of each of these approaches have been highlighted elsewhere. ${ }^{23}$ In brief the first relies on small sample sizes of selected subjects followed up for short periods of time and thus cannot detect either rare or longer comparison group, cannot distinguish between the influence of the drugs and the influence of the indications for their use, especially as severe active RA, with extensive exposure to standard DMARDs, is associated with an increase in several causes of comorbidity. The third, although having the advantage of covering a nationwide population and being useful for detecting very rare events, again ignores the issue of a comparison cohort and relies on physician recognition and reporting of a potentially linked event.

It is important in the interim for prescribing physicians to be aware of current concerns based on these imperfect reporting streams. In this review we have attempted to provide an exhaustive summary of English published reports available in the public domain by the end of 2003. Although it is clear that the number of these publications will continue to grow, our aim is to provide an appropriate source for reference fixed to this point in time. Reports were identified in Embase up to January 2004, using the subject headings etanercept, infliximab, adalimumab, and rheumatoid arthritis. The search was limited to the English language. Adverse events identified through clinical trials, term effects. The second, in the absence of a cohort studies, and case reports/series were included. In addition, the references of retrieved articles were reviewed for any additional reports of adverse events.

\section{INFECTION}

An increased risk of serious infection is a concern after blockade of TNF $\alpha$. A serious infection is defined as any infection resulting in death, disability, or congenital malformation, which requires or extends hospitalisation, or is otherwise deemed medically significant. ${ }^{4}$ TNF $\alpha$ has a crucial role in the body's defence against both bacterial and viral invasion, ${ }^{5}$ particularly in the recruitment of neutrophils, eosinophils, and macrophages to the sites of infection. Therefore, if the effects of TNF $\alpha$ are blocked, patients may be placed at a greater risk of infection. Despite this theoretical concern, the rates of infection seen during clinical trials of etanercept, infliximab, and adalimumab in RA were not significantly increased compared with those in the placebo arms. ${ }^{6-9}$ Minor infections, such as upper respiratory tract infections, were seen frequently, but not at a rate greater than in the placebo group. By contrast, serious infections requiring admission to hospital were rare.

"Controlled trials suggest that infections do not increase when TNF $\alpha$ blockers are used"

As mentioned above, clinical trials may not be powered to detect an increased rate of serious infections. This is particularly true as strict inclusion and exclusion criteria may limit the study to patients at low risk of infection. Despite this, a recent phase IV study of adalimumab, which did not restrict the use of concomitant DMARDs or corticosteroids among the enrolled patients, did not detect an increase in serious infections among treated patients compared with placebo. ${ }^{10}$

In contrast with the absence of an increased rate of serious infections during clinical trials, case reports of serious infections after the use of anti-TNF $\alpha$ have been published. These include at least two cases of necrotising fasciitis, one after the use of etanercept ${ }^{11}$ and a second after infliximab. ${ }^{12}$

Abbreviations: ANA, antinuclear antibody; CHF congestive heart failure; DMARD, disease modifying antirheumatic drug; dsDNA, double stranded DNA; FDA, Federal Drug Administration; MS, multiple sclerosis; RA, rheumatoid arthritis; SLE, systemic lupus erythematosus; TB, tuberculosis; TNF $\alpha$, tumour necrosis factor $\alpha$ 
Patients with RA are already at an increased risk of serious infections in comparison with the general population. ${ }^{13}$ Recently, published cohort studies have attempted to compare the rates of serious infection in patients treated with anti-TNF $\alpha$ agents with historical data from cohorts of patients with RA who were not exposed to these agents. These, however, have shown conflicting results. The South Sweden Registry found no increase in the rates of serious infection among patients receiving infliximab or etanercept compared with those receiving leflunomide. ${ }^{14}$ A second study, from the United States, also found no increase in the rates of infection in the year after the initiation of etanercept treatment, compared with the period before etanercept in the same patients. ${ }^{15}$ However, a third cohort study, also using patients as their own pre-biological controls, did find a more than 20 -fold increase in the infection rate among patients, rising from a rate of 0.008 serious infections/year in the years before anti-TNF $\alpha$ therapy to 0.181 serious infections/year after the start of treatment. ${ }^{16}$

Besides the development of serious bacterial infections, there is also a concern over the development of opportunistic infections in patients receiving anti-TNF $\alpha$ therapies ${ }^{17}$ (table 1). There are reports of reactivated histoplasmosis, ${ }^{18}$ listeriosis, ${ }^{19}$ pulmonary aspergillosis, ${ }^{20}$ and Pneumocystis carinii pneumonia. $^{21}$

However, the infection causing the greatest concern is tuberculosis (TB). The number of reports of TB during the clinical trials was relatively low, with one case reported during a clinical trial of 340 patients treated with infliximab ${ }^{22}$ and 13 cases among 2468 patients during the clinical development phases of adalimumab. ${ }^{17}$ By contrast, there have been no cases reported during clinical trials of etanercept.

There are now numerous case reports of TB developing in patients who have received infliximab. In 2001, 70 cases of TB associated with exposure to infliximab, from an unknown denominator of those treated, were reported, of which 47 had received the drug for RA. ${ }^{23}$ More than $50 \%$ of the cases were extrapulmonary infections. The majority (64\%) of the cases occurred in Europe. Since that report, cases have continued to be reported in patients who have received infliximab, ${ }^{24-34}$ etanercept, ${ }^{35}{ }^{36}$ and adalimumab. ${ }^{27}$ Most of these infections

Table 1 Reports of opportunistic infection among patients receiving anti-TNF $\alpha$ treatment for RA

\begin{tabular}{|c|c|}
\hline Citation & Description of event(s) \\
\hline $\begin{array}{l}\text { Infliximab } \\
\text { De Rosa }^{20} \\
\text { Cursiefen }^{68} \\
\text { True } \\
\text { Maini }^{22} \\
\text { Sawalha }^{70} \\
\text { Nakelchik }^{71} \\
\text { Lee }^{18} \\
\text { Wood } \\
\text { Gluck }^{73} \\
\text { Slifman }^{19} \\
\text { Harney }^{74} \\
\text { Tai }^{21} \\
\text { Hage }^{75}\end{array}$ & $\begin{array}{l}\text { Aspergillus fumigatus pneumonia } \\
\text { Bilateral eyelid molluscum contagiosum } \\
\text { Disseminated cryptococcal infection } \\
\text { Coccidiomycosis } \\
\text { Histoplasma capsulatum panniculitis } \\
\text { Histoplasmosis } \\
\text { Histoplasmosis (5) } \\
\text { Histoplasmosis (2) } \\
\text { Listeriosis (2) } \\
\text { Listeriosis (8) } \\
\text { Peptostreptococcal pericarditis } \\
\text { Pneumocystis carinii pneumonia } \\
\text { Pulmonary cryptococcosis }\end{array}$ \\
\hline $\begin{array}{l}\text { Etanercept } \\
\text { Lee }^{18} \\
\text { Wood }^{72} \\
\text { Slifman }^{19} \\
\text { Phillips } \\
\text { Chopra }^{15} \\
\text { Benz }^{77} \\
\text { Smith }^{78} \\
\text { Carter }^{79}\end{array}$ & $\begin{array}{l}\text { Histoplasmosis } \\
\text { Histoplasmosis } \\
\text { Listeriosis } \\
\text { Mycobacterium avium intracellulare psoas abscess } \\
\text { Mycobacterium marinum tenosynovitis } \\
\text { Necrotising herpetic retinopathy } \\
\text { Parainfluenza virus type } 3 \text { pneumonia } \\
\text { Soft tissue infection neck-Streptococcus constellatus }\end{array}$ \\
\hline
\end{tabular}

have occurred in patients with a known history of TB, suggesting a reactivated infection, but some have occurred in patients with no known previous history of the disease.

\section{"Tuberculosis develops in many patients with infliximab treatment"}

Animal studies have shown that TNF $\alpha$ has a key role in the clearance of mycobacterial infections such as TB, specifically by the formation and maintenance of granulomata which control the infection. Indeed numerous studies have shown that in animals infected with TB subsequent blockade of $\mathrm{TNF} \alpha$ results in fatal reactivation..$^{37} 38$

It is interesting that although etanercept blocks the same cytokine, there have been very few reports of TB after its use. Under the spontaneous pharmacovigilance system, only nine cases of TB among patients receiving etanercept had been reported to the Federal Drug Administration (FDA) compared with the 70 cases with infliximab. ${ }^{23}$ Possible suggestions for this discrepancy include the different mechanisms by which the two agents block TNF $\alpha{ }^{39}$

Interpretation of these data requires knowledge of the underlying risk of $\mathrm{TB}$ among patients from the same geographic area receiving non-biological treatment for RA. Studies from the United States ${ }^{40}$ and Korea ${ }^{41}$ did not suggest any important increased risk, in contrast with a fourfold rise over the level in the general population in Spain. ${ }^{42}$ A more recent study from Spain, based on 1540 patients treated with $\mathrm{TNF} \alpha$ inhibitors, reported 17 cases of TB (all in patients treated with infliximab).$^{43}$ The relative risk of TB in patients with RA treated with infliximab compared with those not treated with anti-TNF $\alpha$ agents was 19.9. As most of the cases of TB after infliximab treatment are felt to represent reactivation rather than de novo disease, the effectiveness of screening patients before treatment will be an important predictor of incidence. Indeed in Spain the risk of TB after infliximab treatment has fallen since national guidelines on the detection and management of latent TB infection were introduced. ${ }^{43}$

\section{NEUROLOGICAL DISEASE}

One unexpected serious adverse event which has been reported after treatment with the anti-TNF $\alpha$ agents, particularly etanercept, is demyelinating disease (table 2). A publication from the FDA Medwatch ${ }^{44}$ system in December 2001 reported 20 cases of neurological disease: 18 after etanercept and two after infliximab. ${ }^{45}$ All cases were temporally associated with the treatment and all cases had a partial or complete response when the treatment was stopped. Sixteen had changes on magnetic resonance imaging consistent with demyelination. These reported numbers are no greater than the expected number in the

Table 2 Reports of neurological disease among patients receiving anti-TNF $\alpha$ treatment for RA

\begin{tabular}{ll}
\hline Citation & Description of event(s) \\
\hline Etanercept $^{\text {Mohan }}{ }^{45}$ & Demyelinating disease (18) \\
Sicotte $^{49}$ & Multiple sclerosis \\
van der Laken & Transverse myelitis \\
Infliximab $_{\text {Mohan }}^{45}$ & \\
Marotte $^{81}$ & Demyelinating disease (2) \\
ten Tusscher $^{82}$ & Aseptic meningitis \\
Hrycai $^{83}$ & Bilateral anterior toxic optic neuropathy \\
\hline
\end{tabular}


Table 3 Reports of autoimmune disease after the use of anti-TNF $\alpha$ treatment for rheumatoid arthritis

\begin{tabular}{|c|c|}
\hline Citation & Description of event(s) \\
\hline \multicolumn{2}{|l|}{ Infliximab } \\
\hline Saleem $^{84}$ & $\begin{array}{l}\text { Acute hepatic injury with interface inflammation in } \\
\text { association with } A N A / \lg G \mathrm{ds} D N A(+)\end{array}$ \\
\hline $\mathrm{Kent}^{85}$ & Bullous skin eruption \\
\hline McCain ${ }^{86}$ & Cutaneous vasculitis \\
\hline \multirow[t]{3}{*}{ Jarrett $^{87}$} & Cutaneous vasculitis (5) \\
\hline & Mononeuritis multiplex \\
\hline & CNS vasculitis \\
\hline Geborek $^{14}$ & Leucocyłoclastic vasculitis \\
\hline Fitzcharles $^{88}$ & Leucocytoclastic vasculitis (2) \\
\hline Musial $^{89}$ & Polymyositis \\
\hline Favalli $^{90}$ & Systemic lupus erythematosus \\
\hline Debandt ${ }^{91}$ & Systemic lupus erythematosus \\
\hline \multicolumn{2}{|l|}{ Etanercept } \\
\hline Galaria $^{92}$ & Cutaneous vasculitis \\
\hline McCain ${ }^{86}$ & Cutaneous vasculitis* \\
\hline Cunnane $^{93}$ & Cutaneous vasculitis \\
\hline \multirow[t]{2}{*}{ Misery ${ }^{94}$} & Discoid lupus \\
\hline & Cutaneous necrotising vasculitis \\
\hline \multirow[t]{2}{*}{ Brion ${ }^{95}$} & Discoid lupus \\
\hline & Necrotising vasculitis \\
\hline Soliotis $^{96}$ & Erythema multiforme \\
\hline Berthelot $^{97}$ & Lethal medium vessel vasculitis \\
\hline Jarreft $^{87}$ & Leucocytoclastic vasculitis \\
\hline Caramaschi ${ }^{98}$ & Orbital myositis \\
\hline Andres $^{99}$ & Silent thyroiditis \\
\hline Bleumink $^{100}$ & Subacute cutaneous lupus erythematosus (2) \\
\hline Shakoor ${ }^{101}$ & Systemic lupus erythematosus \\
\hline Cairns $^{102}$ & Systemic lupus erythematosus \\
\hline Swale ${ }^{103}$ & Systemic lupus erythematosus \\
\hline Debandt $^{91}$ & Systemic lupus erythematosus (2) \\
\hline Geborek $^{14}$ & Systemic lupus erythematosus \\
\hline & Discoid lupus* ${ }^{*}$ \\
\hline
\end{tabular}

general population based on the estimated number of patients treated with etanercept. ${ }^{45}$

Levels of TNF $\alpha$ are increased both in the cerebrospinal fluid and in the circulation in patients with active multiple sclerosis (MS), ${ }^{46} 47$ and thus it might be expected that anti$\mathrm{TNF} \alpha$ therapy might be beneficial in this group of disorders. However, the results of two studies of anti-TNF $\alpha$ therapy, one of infliximab and another with lenercept (a soluble TNF $\alpha$ p55 receptor), actually found a worsening of clinical disease in patients with known MS. ${ }^{48}$ The reasons for this are not understood. ${ }^{47}$ It is of concern, however, that there are reports of MS developing in patients treated with anti-TNF $\alpha$ with no known history of neurological disease. ${ }^{49}$ Although the coincidental onset of both diseases in the same patient is entirely possible, it is also feasible that the drug has triggered latent demyelination or, in fact, has caused the disease.

\section{AUTOIMMUNE DISEASE}

The development of autoantibodies, including antinuclear antibody (ANA) and anti-double stranded DNA antibodies (anti-dsDNA), after the use of anti-TNF $\alpha$ therapies was well documented during the clinical trials of these agents. About $60 \%$ of patients enrolled in the ATTRACT study developed a new ANA and 10\% developed new anti-dsDNA at some point during treatment with infliximab. ${ }^{50}$ The pathological significance of these observations is uncertain. Only one patient developed a lupus-like syndrome during the study.2 ${ }^{22}$ The development of new ANA and anti-dsDNA has also been reported in about $10 \%$ of patients receiving either adalimumab or etanercept during phase III clinical trials, ${ }^{67}{ }^{9}$ but with no cases of systemic lupus erythematosus (SLE).
By contrast, post-marketing surveillance of these agents has disclosed numerous case reports of autoimmune disease, particularly leucocytoclastic vasculitis and SLE (table 3). Most of these developed after starting anti-TNF $\alpha$ therapy, improved when it was discontinued, and were not life threatening. In some cases, patients were known to have a positive ANA before the start of anti-TNF $\alpha$ therapy. In interpreting these case reports it is noted that patients with one autoimmune disease, such as RA, do have an increased frequency of a second autoimmune disease, particularly SLE, ${ }^{5152}$ and the reports of these reactions may simply represent coincidental disease. However, drug-induced lupus is not an uncommon phenomenon. The development of new autoantibodies with the use of anti-TNF $\alpha$ therapy suggests these drugs may, in some patients, have a causative role.

\section{CARDIAC DISEASE}

Another major area of concern has been in relation to cardiac disease, particularly the possibility that anti-TNF $\alpha$ therapy may lead to worsening of congestive heart failure (CHF). As with MS, this concern is initially counterintuitive as serum levels of $\mathrm{TNF} \alpha$ are raised in patients with CHF and indeed correlate with the severity of $\mathrm{CHF}^{53}$ Early reports suggested that treatment with a single dose of intravenous etanercept in patients with severe CHF might improve symptoms without significant side effects. ${ }^{54}$ Two large randomised, placebo controlled trials of anti-TNF $\alpha$ agents in patients with CHF were undertaken. The first study, RENAISSANCE/RECOVER, compared etanercept with placebo in patients with advanced heart failure..$^{55}$ It failed to detect any improvement in either CHF symptoms or mortality after etanercept treatment. The second study, ATTACH, compared infliximab with placebo in patients with advanced heart failure. ${ }^{56}$ This study observed an increased rate of death and admission to hospital in the infliximab group. It is not clear why treatment with infliximab should exacerbate CHF, but the increased mortality was only seen in the group receiving $10 \mathrm{mg} / \mathrm{kg}$ infliximab. For most patients, this exceeds the dose recommended for RA. ${ }^{57}$ No increased mortality was seen at the lower dose of $5 \mathrm{mg} / \mathrm{kg}$.

\section{"Congestive heart failure may be exacerbated when high dose infliximab is used"}

An analysis from the FDA Medwatch system has now reported the development of CHF in 47 patients who had received anti-TNF $\alpha$ therapy, the majority for $\mathrm{RA}^{38}$ with a lesser number for Crohn's disease, ${ }^{6}$ psoriatic arthritis, ${ }^{1}$ juvenile idiopathic arthritis, ${ }^{1}$ and one unknown underlying diagnosis. ${ }^{58}$ Forty per cent had new onset CHF without documented risk factors (15 patients with RA, 4 other), 40\% developed new onset CHF but with documented risk factors (14 patients with RA, 5 other), and in 9 exacerbation of known CHF occurred (all patients with RA). Of those with new onset CHF, $68 \%$ had received etanercept and 32\% had received infliximab. Of the patients with an exacerbation of known CHF, 33\% had received etanercept and 66\% infliximab. The median time to onset of CHF was 2.5-4 months. The majority of patients were aged 50 years or older. Of concern, however, are the 10 patients aged less than 50 (five with RA) with new onset of CHF. Only three of these patients reported an underlying risk factor for CHF. In most patients symptoms of CHF have resolved or improved with treatment. Three patients had died at the time of the report.

Case reports have also appeared of other cardiac conditions in patients with RA receiving anti-TNF $\alpha$ drugs. These include a case of sudden death, without organic cause on necropsy, in a 64 year old man with no known underlying cardiac disease 
Table 4 Reports of haematological disease after the use of anti-TNF $\alpha$ treatment for RA

\begin{tabular}{|c|c|}
\hline Citation & Description of event(s) \\
\hline \multicolumn{2}{|l|}{ Infliximab } \\
\hline Kavanaugh $^{8}$ & B cell lymphoma \\
\hline Brown ${ }^{104}$ & Lymphoproliferative malignancy (15) \\
\hline Geborek $^{14}$ & $\begin{array}{l}\text { Non-Hodgkin's lymphoma (1) } \\
\text { Hodgkin's disease (1) }\end{array}$ \\
\hline Aouba $^{105}$ & Haemophagocytic syndrome \\
\hline Marchesoni ${ }^{65}$ & Bone marrow hypoplasia \\
\hline \multicolumn{2}{|l|}{ Etanercept } \\
\hline Brown $^{104^{4}}$ & Lymphoproliferative malignancy (3) \\
\hline Kremer ${ }^{106}$ & Non-Hodgkin's lymphoma \\
\hline Bathon $^{107}$ & Hodgkin's disease \\
\hline Geborek $^{14}$ & Immunocytoma of breast (1) \\
\hline & Acute myeloid leukaemia (1) \\
\hline Kuruvilla $^{66}$ & Aplastic anaemia \\
\hline \multicolumn{2}{|l|}{ Adalimumab } \\
\hline Ziakas $^{108}$ & Mantle cell lymphoma \\
\hline
\end{tabular}

who was receiving infliximab. ${ }^{59}$ There has also been a case report of new onset atrial fibrillation in a 57 year old man receiving etanercept. ${ }^{60}$

Care should be taken when interpreting the onset of CHF in patients with RA receiving anti-TNF $\alpha$ therapy. Cardiovascular disease is the leading cause of death among patients with RA, with increased standardised mortality ratios, compared with the general population. ${ }^{61-63}$ These increased ratios suggest that patients with RA are already dying from cardiovascular disease in excess of the level expected for people in the general population of the same age and sex.

\section{HAEMATOLOGICAL DISEASE (INCLUDING MALIGNANCY)}

Finally, concern has been raised about haematological abnormalities after the use of anti-TNF $\alpha$ therapies in RA (table 4). These include lymphoproliferative malignancies and cytopenia. We have recently reviewed the former. ${ }^{64}$

There has also been the concern about bone marrow suppression with the use of anti-TNF $\alpha$ agents in RA. These include a report of pancytopenia after the use of infliximab ${ }^{65}$ and a report of aplastic anaemia after treatment with etanercept. ${ }^{66}$ An FDA briefing has also reported two additional cases of aplastic anaemia and seven cases of pancytopenia after the use of etanercept for RA. ${ }^{67}$ Caution must be used in interpreting the role of anti-TNF $\alpha$ therapy in each of these cases. All cases developed in patients with chronic RA receiving multiple drugs. The exact part played by the anti-TNF $\alpha$ drug is unknown.

\section{SUMMARY}

The advent of anti-TNF $\alpha$ therapy is an important advance in the management of RA. However, reports about the safety of anti-TNF $\alpha$ therapy, including a risk of serious infection, congestive heart failure, malignancy, and MS, have been accumulating in the literature. However, it is difficult to interpret the importance of these events, because of both underreporting and uncertainty about the actual number of patients treated. The results also do not account for the baseline risk of serious adverse events associated with RA and its conventional treatment.

This review emphasises the need for systematic follow up and registries of patients receiving these drugs. The biggest challenge will be to find an appropriate comparison group of patients with RA not receiving anti-TNF $\alpha$ therapies. It is important when calculating risk that the comparison cohort has similar duration and severity of disease, such that the expected event rate will accurately reflect that of an antiTNF $\alpha$ treated cohort. However, as the anti-TNF $\alpha$ therapies become more widely available, it will become more difficult to collect this comparison cohort prospectively. To deal with these methodological issues, several countries within Europe (including the United Kingdom, Sweden, Germany, and Spain), as well as the National Databank for Rheumatic Diseases in the United States, have established registries, which will include a comparison cohort of patients with RA receiving non-biological antirheumatic treatments. However, it is likely to be some years before robust answers are available on the magnitude of any risk associated with exposure to anti-TNF $\alpha$ agents.

\section{Authors' affiliations}

K L Hyrich, A J Silman, K D Watson, D P M Symmons, ARC

Epidemiology Unit, University of Manchester, UK

\section{REFERENCES}

1 Taylor PC. Anti-tumor necrosis factor therapies. Curr Opin Rheumatol 2001;13:164-9.

2 Pincus T, Stein CM. Why randomized controlled clinical trials do not depict accurately long-term outcomes in rheumatoid arthritis: some explanations and suggestions for future studies. Clin Exp Rheumatol 1997;15(suppl 17):S27-38.

3 Goldman SA. Limitations and strengths of spontaneous reports data. Clin Ther 1998;20(suppl C):C40-4.

4 Edwards IR, Aronson JK. Adverse drug reactions: definitions, diagnosis, and management. Lancet 2000;356:1255-9.

5 Camussi G, Albano E, Tetta C, Bussolino F. The molecular action of tumor necrosis factor-alpha. Eur J Biochem 1991;202:3-14.

6 Moreland LW, Schiff MH, Baumgartner SW, Tindall EA, Fleischmann RM, Bulpitt KJ, et al. Etanercept therapy in rheumatoid arthritis. A randomized, controlled trial. Ann Intern Med 1999;130:478-86.

7 Weinblatt ME, Kremer JM, Bankhurst AD, Bulpitt KJ, Fleischmann RM, Fox RI, et al. A trial of etanercept, a recombinant tumor necrosis factor receptor: Fc fusion protein, in patients with rheumatoid arthritis receiving methotrexate. N Engl J Med 1999;340:253-9.

8 Kavanaugh A, St Clair EW, McCune WJ, Braakman T, Lipsky P. Chimeric anti-tumor necrosis factor-alpha monoclonal antibody treatment of patients with rheumatoid arthritis receiving methotrexate therapy. J Rheumatol 2000;27:841-50.

9 Weinblatt ME, Keystone EC, Furst DE, Moreland LW, Weisman MH, Birbara CA, et al. Adalimumab, a fully human anti-tumor necrosis factor alpha monoclonal antibody, for the treatment of rheumatoid arthritis in patients taking concomitant methotrexate: the ARMADA trial. Arthritis Rheum 2003;48:35-45.

10 Furst DE, Schiff MH, Fleischmann RM, Strand V, Birbara CA, Compagnone D, et al. Adalimumab, a fully human anti-tumor necrosis factor- $\alpha$ monoclonal antibody, and concomitant standard antirheumatic therapy for the treatment of rheumatoid arthritis: results of STAR (Safety Trial of Adalimumab in Rheumatoid Arthritis). J Rheumatol 2003:30:2563-71.

11 Baghai M, Osmon DR, Wolk DM, Wold LE, Haidukewych GJ, Matteson EL. Fatal sepsis in a patient with rheumatoid arthritis treated with etanercept. Mayo Clin Proc 2001;76:653-6.

12 Chan AT, Cleeve V, Daymond TJ. Necrotising fasciitis in a patient receiving infliximab for rheumatoid arthritis. Postgrad Med J 2002;78:47-8.

13 Doran MF, Crowson CS, Pond GR, O'Fallon WM, Gabriel SE. Frequency of infection in patients with rheumatoid arthritis compared with controls: a population-based study. Arthritis Rheum 2002;46:2287-93.

14 Geborek P, Crnkic M, Petersson IF, Saxne T. Etanercept, infliximab, and leflunomide in established rheumatoid arthritis: clinical experience using a structured follow up programme in southern Sweden. Ann Rheum Dis 2002;61:793-8

15 Phillips K, Husni ME, Karlson EW, Coblyn JS. Experience with etanercept in an academic medical center: are infection rates increased? Arthritis Care Res 2002;47:17-21

16 Kroesen S, Widmer AF, Tyndall A, Hasler P. Serious bacterial infections in patients with rheumatoid arthritis under anti-TNF-alpha therapy. Rheumatology (Oxford) 2003;42:617-21.

17 Ellerin T, Rubin RH, Weinblatt ME. Infections and anti-tumor necrosis factor $\alpha$ therapy. Arthritis Rheum 2003;48:3013-21.

18 Lee JH, Slifman NR, Gershon SK, Edwards ET, Schwieterman WD, Siegel JN, et al. Life-threatening histoplasmosis complicating immunotherapy with tumor necrosis factor alpha antagonists infliximab and etanercept. Arthritis Rheum 2002;46:2565-70.

19 Slifman NR, Gershon SK, Lee J-H, Edwards ET, Braun MM. Listeria monocytogenes infection as a complication of treatment with tumor necrosis factor $\alpha$-neutralizing agents. Arthritis Rheum 2003;48:319-24.

20 De Rosa FG, Shaz D, Campagna AC, Dellaripa PF, Khettry U, Craven DE. Invasive pulmonary aspergillosis soon after therapy with infliximab, a tumor 
necrosis factor-alpha-neutralizing antibody: a possible healthcareassociated case? Infect Control Hosp Epidemiol 2003;24:477-82

21 Tai TL, O'Rourke KP, McWeeney M, Burke CM, Sheehan K, Barry M. Pneumocystis carinii pneumonia following a second infusion of infliximab. Rheumatology (Oxford) 2002;41:951-2.

22 Maini R, St Clair EW, Breedveld F, Furst D, Kalden J, Weisman M, et al. Infliximab (chimeric anti-tumour necrosis factor alpha monoclonal antibody) versus placebo in rheumatoid arthritis patients receiving concomitant methotrexate: a randomised phase III trial. ATTRACT Study Group. Lancet 1999;354:1932-9.

23 Keane J, Gershon S, Wise RP, Mirabile-Levens E, Kasznica J, Schwieterman WD, et al. Tuberculosis associated with infliximab, a tumor necrosis factor $\alpha$-neutralizing agent. N Engl J Med 1, 345:1098-104.

24 Temekonidis TI, Georgiadis AN, Alamanos Y, Bougias DV, Voulgari PV, Drosos AA. Infliximab treatment in combination with cyclosporin $A$ in patients with severe refractory rheumatoid arthritis. Ann Rheum Dis 2002;61:822-5.

25 Vonkeman HE, Van Der Valk PDLP, Mulder L, Van de Laar MAFJ. Fatal extrapulmonary tuberculosis during treatment with the immunosuppresive infliximab. Ned Tijdschr Geneeskd 2002;146:1 196-9.

26 Shergy WJ, Isern RA, Cooley DA, Harshbarger JL, Huffstutter JE, Hughes $G M$, et al. Open label study to assess infliximab safety and timing of onset of clinical benefit among patients with rheumatoid arthritis. J Rheumatol 2002;29:667-77.

27 Flendrie M, Creemers MCW, Welsing PMJ, den Broeder AA, Van Riel PLCM. Survival during treatment with tumour necrosis factor blocking agents in rheumatoid arthritis. Ann Rheum Dis 2003;62(suppl II):ii30-3.

28 Sidiropoulos P, Bertsias G, Kritikos HD, Kouroumali H, Voudouris K, Boumpas DT. Infliximab treatment for rheumatoid arthritis, with dose titration based on the Disease Activity Score: dose adjustments are common but not always sufficient to assure sustained benefit. Ann Rheum Dis 2004;63:144-8.

29 Van Der Klooster JM, Bosman RJ, Oudemans-van Straaten HM, van der Spoel JI, Wester JP, Zandstra DF. Disseminated tuberculosis, pulmonary aspergillosis and cutaneous herpes simplex infection in a patient with infliximab and methotrexate. Intensive Care Med 2003;29:2327-9.

30 Rovere Querini P, Vecellio M, Sabbadini MG, Ciboddo G. Miliary tuberculosis after biological therapy for rheumatoid arthritis. Rheumatology (Oxford) 2002:41:231.

31 Mayordomo L, Marenco JL, Gomez-Mateos J, Rejon E. Pulmonary miliary tuberculosis in a patient with anti-TNF-alpha treatment. Scand I Rheumatol 2002;31:44-5.

32 Cairns AP, Taggart AJ. Anti-tumour necrosis factors therapy for severe inflammatory arthritis: two years of experience in Northern Ireland. Ulster Med J 2002;71:101-5

33 Taylor JC, Orkin R, Lanham J. Tuberculosis following therapy with infliximab may be refractory to antibiotic therapy. Rheumatology (Oxford) 2003:42:901-2.

34 Parra RJ, Ortego CN, Raya AE. Development of tuberculosis in a patient treated with infliximab who had received prophylactic therapy with isoniazid. J Rheumatol 2003;30:1657-8.

35 Manadan AM, Block JA, Sequeira W. Mycobacteria tuberculosis peritonitis associated with etanercept therapy. Clin Exp Rheumatol 2003;21:526.

36 Derk CT, DeHoratius RJ. Tuberculous tonsillitis in a patient receiving etanercept treatment. Ann Rheum Dis 2003;62:372.

37 Kaneko H, Yamada H, Mizuno S, Udagawa T, Kazumi Y, Sekikawa K, et al. Role of tumor necrosis factor-alpha in Mycobacterium-induced granuloma formation in tumor necrosis factor-alpha-deficient mice. Lab Invest 1999;79:379-86.

38 Kindler V, Sappino AP, Grau GE, Piguet PF, Vassalli P. The inducing role of tumor necrosis factor in the development of bactericidal granulomas during BCG infection. Cell 1989;56:731-40.

39 Gardam MA, Keystone EC, Menzies R, Manners S, Skamene E, Long R, et al. Anti-tumour necrosis factor agents and tuberculosis risk: mechanisms of action and clinical management. Lancet Infect Dis 2003:3:148-55.

40 Wolfe F, Flowers N, Anderson J, Urbansky K. Tuberculosis rates are not increased in rheumatoid arthritis (RA) [abstract]. Arthritis Rheum 2001;44(suppl 9):S318.

41 Yun JE, Lee SW, Kim TH, Jun JB, Jung S, Bae SC, et al. The incidence and clinical characteristics of Mycobacterium tuberculosis infection among systemic lupus erythematosus and rheumatoid arthritis patients in Korea. Clin Exp Rheumatol 2002;20:127-32.

42 Carmona L, Hernandez-Garcia C, Vadillo C, Pato E, Balsa A, GonzalezAlvaro I, et al. Increased risk of tuberculosis in patients with rheumatoid arthritis. J Rheumatol 2003;30:1436-9.

43 Gomez-Reino JJ, Carmona L, Valverde VR, Mola EM, Montero MD. Treatment of rheumatoid arthritis with tumor necrosis factor inhibitors may predispose to significant increase in tuberculosis risk: a multicenter activesurveillance report. Arthritis Rheum 2003;48:2122-7.

44 Kessler DA. Introducing MEDWatch. A new approach to reporting medication and device adverse effects and product problems. JAMA 1993:269:2765-8

45 Mohan N, Edwards ET, Cupps TR, Oliverio PJ, Sandberg G, Crayton H, et al. Demyelination occurring during anti-tumor necrosis factor alpha therapy for inflammatory arthritides. Arthritis Rheum 2001;44:2862-9.

46 Selmaj KW. Tumour necrosis factor and anti-tumour necrosis factor approach to inflammatory demyelinating diseases of the central nervous system. Ann Rheum Dis 2000;59(suppl I)::i94-102.

47 Lock C, Oksenberg J, Steinman L. The role of TNFalpha and lymphotoxin in demyelinating disease. Ann Rheum Dis 1999:58(suppl I):i121-8.
48 TNF neutralization in MS: results of a randomized, placebo-controlled multicenter study. The Lenercept Multiple Sclerosis Study Group and The University of British Columbia MS/MRI Analysis Group. Neurology 1999:53:457-65.

49 Sicotte NL, Voskuhl RR. Onset of multiple sclerosis associated with anti-TNF therapy. Neurology 2001;57:1885-8.

50 Lipsky PE, van der Heijde DMFM, St Clair EW, Furst DE, Breedveld FC, Kalden JR, et al. Infliximab and methotrexate in the treatment of rheumatoid arthritis. N Engl J Med 2000;343:1594-602.

51 Brand CA, Rowley MJ, Tait BD, Muirden KD, Whittingham SF. Coexistent rheumatoid arthritis and systemic lupus erythematosus: clinical, serological, and phenotypic features. Ann Rheum Dis 1992:51:173-6.

52 Cohen MG, Webb J. Concurrence of rheumatoid arthritis and systemic lupus erythematosus: report of 11 cases. Ann Rheum Dis 1987;46:853-8.

53 Torre-Amione G, Kapadia S, Lee J, Durand JB, Bies RD, Young JB, et al. Tumor necrosis factor-alpha and tumor necrosis factor receptors in the failing human heart. Circulation 1996:93:704-11

54 Deswal A, Bozkurt B, Seta Y, Parilti-Eiswirth S, Hayes FA, Blosch C, et al. Safety and efficacy of a soluble P75 tumor necrosis factor receptor (Enbrel, etanercept) in patients with advanced heart failure. Circulation 1999:99:3224-6.

55 Anker SD, Coats AJ. How to RECOVER from RENAISSANCE? The significance of the results of RECOVER, RENAISSANCE, RENEWAL and ATTACH. Int I Cardiol 2002;86:123-30.

56 Chung ES, Packer M, Lo KH, Fasanmade AA, Willerson JT. Randomized, double-blind, placebo-controlled, pilot trial of infliximab, a chimeric monoclonal antibody to tumor necrosis factor-alpha, in patients with moderate-to-severe heart failure: results of the anti-TNF Therapy Against Congestive Heart Failure (ATACH) trial. Circulation 2003;107:3133-40.

57 British Society for Rheumatology. Guidelines for prescribing TNF- $\alpha$ blockers in adults with rheumatoid arthritis. London: British Society of Rheumatology, http://www.msecportal.org/portal/editorial/PublicPages/bsr/ $536883013 / 1$.doc (accessed 13 September 2004).

58 Kwon HJ, Cote TR, Cuffe MS, Kramer JM, Braun MM. Case reports of heart failure after therapy with a tumor necrosis factor antagonist. Ann Intern Med 2003;138:807-11.

59 de'Clari F, Salani I, Safwan E, Giannacco A. Sudden death in a patient without heart failure after a single infusion of $200 \mathrm{mg}$ infliximab: does TNFalpha have protective effects on the failing heart, or does infliximab have direct harmful cardiovascular effects? Circulation 2002;105:E183.

60 Wooten MD, Reddy GV, Johnson RD. Atrial fibrillation occurring in a patient taking etanercept plus methotrexate for rheumatoid arthritis. Del Med J 2000;72:517-19.

61 Watson DJ, Rhodes T, Guess HA. All-cause mortality and vascular events among patients with rheumatoid arthritis, osteoarthritis, or no arthritis in the UK General Practice Research Database. J Rheumatol 2003;30:1 196-202.

62 Solomon DH, Karlson EW, Rimm EB, Cannuscio CC, Mandl LA, Manson JE, et al. Cardiovascular morbidity and mortality in women diagnosed with rheumatoid arthritis. Circulation 2003;107:1303-7.

63 Prior P, Symmons DP, Scott DL, Brown R, Hawkins CF. Cause of death in rheumatoid arthritis. BrJ Rheumatol 1984:23:92-9.

64 Symmons DPM, Silman AJ. Anti-TNF $\alpha$ therapy and the risk of lymphoma in rheumatoid arthritis: no clear answer. Arthritis Rheum 2004;50:1703-6.

65 Marchesoni A, Arreghini M, Panni B, Battafarano N, Uziel L. Life-threatening reversible bone marrow toxicity in a rheumatoid arthritis patient switched from leflunomide to infliximab. Rheumatology (Oxford) 2003:42:193-4.

66 Kuruvilla J, Leitch HA, Vickars LM, Galbraith PF, Li CH, Al Saab S, et al. Aplastic anemia following administration of a tumor necrosis factor- $\alpha$ inhibitor. Eur J Haematol 2003;71:396-8.

67 US Food and Drug Administration. Safety Update on TNF-alphe Antagonists: Infliximab and Etanercept. http://www.fda.gov/ohrms/ dockets/ac/01/briefing/3779b2_01_cber_safety\% 20_revision2.pdf (accessed 10 February 2003).

68 Cursiefen C, Grunke M, Dechant C, Antoni C, Junemann A, Holbach LM. Multiple bilateral eyelid molluscum contagiosum lesions associated with TNFalpha-antibody and methotrexate therapy. Am J Ophthalmol 2002;134:270-1.

69 True DG, Penmetcha M, Peckham SJ. Disseminated cryptococcal infection in rheumatoid arthritis treated with methotrexate and infliximab. I Rheumatol 2002;29:1561-3.

70 Sawalha AH, Lutz BD, Chaudhary NA, Kern W, Harley JB, Greenfield RA. A presenting manifestation of disseminated histoplasmosis in a patient with rheumatoid arthritis. J Clin Rheumatol 2003;9:259-2.

71 Nakelchik M, Mangino JE. Reactivation of histoplasmosis after treatment with infliximab. Am J Med 2002;1 12:78.

72 Wood KL, Hage CA, Knox KS, Kleiman MB, Sannuti A, Day RB, et al. Histoplasmosis after treatment with anti-tumor necrosis factor-alpha therapy. Am J Respir Crit Care Med 2003;167:1279-82.

73 Gluck T, Linde HJ, Scholmerich J, Muller-Ladner U, Fiehn C, Bohland P. Antitumor necrosis factor therapy and Listeria monocytogenes infection: report of two cases. Arthritis Rheum, 2002:46:2255-7.

74 Harney S, O'Shea FD, FitzGerald O. Peptostreptococcal pericarditis complicating anti-tumour necrosis factor alpha treatment in rheumatoid arthritis. Ann Rheum Dis 2002;61:653-4.

75 Hage CA, Wood KL, Winer-Muram HT, Wilson SJ, Sarosi G, Knox KS Pulmonary cryptococcosis after initiation of anti-fumor necrosis factor-alpha therapy. Chest 2003;124:2395-7.

76 Chopra N, Kirschenbaum AE, Widman D. Mycobacterium marinum tenosynovitis in a patient on etanercept therapy for rheumatoid arthritis. JCR J Clin Rheumatol 2002;8:265-8. 
77 Benz MS, Glaser JS, Davis JL. Progressive outer retinal necrosis in immunocompetent patients treated initially for optic neuropathy with systemic corticosteroids. Am J Ophthalmol 2003;135:551-3.

78 Smith D, Letendre S. Viral pneumonia as a serious complication of etanercept therapy. Ann Intern Med 2002;136:174.

79 Carter JD, Kanik KS, Valeriano J. Neck mass in a rheumatoid arthritis patient taking etanercept. JCR J Clin Rheumatol 2000;6:80-1.

80 van der Laken CJ, Lems WF, van Soesbergen RM, van der Sande JJ, Dijkmans BAC. Paraplegia in a patient receiving anti-tumor necrosis factor therapy for rheumatoid arthritis: Comment on the article by Mohan, et al. Arthritis Rheum 2003;48:269-70.

81 Marotte H, Charrin JE, Miossec P. Infliximab-induced aseptic meningitis. Lancet 2001;358:24.

82 ten Tusscher MP, Jacobs PJ, Busch MJ, de Graaf L, Diemont WL. Bilateral anterior toxic optic neuropathy and the use of infliximab. BMJ 2003;326:579.

83 Hrycaj P, Korczowska I, Lacki JK. Severe Parkinson's disease in rheumatoid arthritis patient treated with infliximab. Rheumatology (Oxford) 2003:42:702-3.

84 Saleem G, Li SC, MacPherson BR, Cooper SM, Charles P, Maini RM. Hepatitis with interface inflammation and $\lg G, \lg M$, and $\lg A$ anti-doublestranded DNA antibodies following infliximab therapy: Comment on the article by Charles, et al. Arthritis Rheum 2001;44:1966-8.

85 Kent PD, Davis JM, III, Davis MD, Matteson EL. Bullous skin lesions following infliximab infusion in a patient with rheumatoid arthritis. Arthritis Rheum 2002;46:2257-8.

86 McCain ME, Quinet RJ, Davis WE. Etanercept and infliximab associated with cutaneous vasculitis. Rheumatology (Oxford) 2002;41:116-17.

87 Jarrett SJ, Cunnane G, Conaghan PG, Bingham SJ, Buch MH, Quinn MA, et al. Anti-tumor necrosis factor- $\alpha$ therapy-induced vasculitis: case series. $J$ Rheumatol 2003;30:2287-91.

88 Fitzcharles M-A, Clayton D, Menard HA. The use of infliximab in academic rheumatology practice: an audit of early clinical experience. J Rheumatol 2002;29:2525-30

89 Musial J, Undas A, Celinska-Lowenhoff M. Polymyositis associated with infliximab treatment for rheumatoid arthritis. Rheumatology (Oxford) 2003:42:1556-8.

90 Favalli EG, Sinigaglia L, Varenna M, Arnoldi C. Drug-induced lupus following treatment with infliximab in rheumatoid arthritis. Lupus 2002;11:753-5.

91 Debandt M, Vittecoq O, Descamps V, Le Loet X, Meyer O. Anti-TNF-alphainduced systemic lupus syndrome. Clin Rheumatol 2003;22:56-61.

92 Galaria NA, Werth VP, Schumacher HR. Leukocyłoclastic vasculitis due to etanercept. J Rheumatol 2000;27:2041-4.

93 Cunnane G, Warnock M, Fye KH, Daikh DI. Accelerated nodulosis and vasculitis following etanercept therapy for rheumatoid arthritis. Arthritis Care Res 2002;47:445-9.
94 Misery L, Perrot JL, Gentil-Perret A, Pallot-Prades B, Cambazard F, Alexandre $C$. Dermatological complications of etanercept therapy for rheumatoid arthritis. Br J Dermatol 2002;146:334-5.

95 Brion PH, Mittal-Henkle A, Kalunian KC. Autoimmune skin rashes associated with etanercept for rheumatoid arthritis. Ann Intern Med 1999;131:634.

96 Soliotis F, Glover M, Jawad ASM. Severe skin reaction after leflunomide and etanercept in a patient with rheumatoid arthritis. Ann Rheum Dis 2002;61:850-1.

97 Berthelot J-M, Glemarec J, Maugars Y, Prost A. Lethal medium-vessel panarteritis mimicking deep sepsis following etanercept and minocycline therapy in a patient with severe rheumatoid arthritis. Rheumatology (Oxford) 2002:41:703-5.

98 Caramaschi P, Biasi D, Carletto A, Bambara LM. Orbital myositis in a rheumatoid arthritis patient during entanercept treatment. Clin Exp Rheumatol 2003;21:136-7.

99 Andres E, Limbach FX, Goichot B, Sibilia J. Silent thyroiditis associated with etanercept in rheumatoid arthritis. Ann Rheum Dis 2002;61:565.

100 Bleumink GS, ter Borg EJ, Ramselaar CG, Ch Stricker BH. Etanerceptinduced subacute cutaneous lupus erythematosus. Rheumatology (Oxford) 2001:40:1317-19.

101 Shakoor N, Michalska M, Harris CA, Block JA. Drug-induced systemic lupus erythematosus associated with etanercept therapy. Lancet 2002;359:579-80.

102 Cairns AP, Duncan MKJ, Hinder AE, Taggart AJ. New onset systemic lupus erythematosus in a patient receiving etanercept for rheumatoid arthritis. Ann Rheum Dis 2002;61:1031-2.

103 Swale VJ, Perrett CM, Denton CP, Black CM, Rustin MHA. Etanerceptinduced systemic lupus erythematosus. Clin Exp Dermatol 2003;28:604-7.

104 Brown SL, Greene MH, Gershon SK, Edwards ET, Braun MM. Tumor necrosis factor antagonist therapy and lymphoma development: twenty-six cases reported to the Food and Drug Administration. Arthritis Rheum 2002;46:3151-8.

105 Aouba A, De Bandt M, Aslangul E, Atkhen N, Patri B. Haemophagocytic syndrome in a rheumatoid arthritis patient treated with infliximab. Rheumatology (Oxford) 2003;42:800-2.

106 Kremer JM, Weinblatt ME, Bankhurst AD, Bulpitt KJ, Fleischmann RM Jackson CG, et al. Etanercept added to background methotrexate therapy in patients with rheumatoid arthritis: continued observations. Arthritis Rheum 2003;48:1493-9.

107 Bathon JM, Martin RW, Fleischmann RM, Tesser JR, Schiff MH, Keystone EC, et al. A comparison of etanercept and methotrexate in patients with early rheumatoid arthritis. N Engl J Med 2000;343:1586-93.

108 Ziakas PD, Giannouli S, Tzioufas AG, Voulgarelis M. Lymphoma development in a patient receiving anti-TNF therapy. Haematologica 2003;88:ECR25. 